\title{
Feeding Behaviour of the Mussel, Mytilus edulis: New Observations, with a Minireview of Current Knowledge
}

\author{
Hans Ulrik Riisgård, Parnuna P. Egede, and Isabel Barreiro Saavedra \\ Marine Biological Research Centre, University of Southern Denmark, Hindsholmvej 11, 5300 Kerteminde, Denmark \\ Correspondence should be addressed to Hans Ulrik Riisgård, hur@biology.sdu.dk
}

Received 15 June 2011; Accepted 21 July 2011

Academic Editor: Norman Ying Shiu Woo

Copyright (C) 2011 Hans Ulrik Riisgård et al. This is an open access article distributed under the Creative Commons Attribution License, which permits unrestricted use, distribution, and reproduction in any medium, provided the original work is properly cited.

\begin{abstract}
Under optimal conditions, bivalves tend to filter the ambient water at a maximum rate but under suboptimal environmental conditions, including low or very high algal concentrations, the filtration rate is reduced. The upper algal concentration at which the blue mussel, Mytilus edulis, exploits its filtration capacity over an extended period of time was identified by stepwise raising the algal (Rhodomonas salina) concentration in steady-state experiments above the threshold for continuous high filtration rate. The duration time before incipient saturation reduction decreased with increasing algal concentration, and the threshold concentration for incipient saturation reduction of filtration activity was found to be between about 5,000 and 8,000 cells $\mathrm{mL}^{-1}$, equivalent to 6.3 and $10.0 \mu \mathrm{g} \mathrm{chl} a \mathrm{~L}^{-1}$, respectively. Reduced filtration rate was related to total number of algal cells ingested previous to incipient saturation and found to be $11.4 \pm 1.7 \times 10^{6}$ cells. Video-microscope recordings of pseudofaeces production revealed that the trigger threshold concentration for formation of pseudofaeces was about $12,000 \mathrm{cells} \mathrm{mL}^{-1}$. Faeces produced by saturated mussels consisted of closely packed undigested algal cells, indicating severe overloading of the digestive system caused by high algal concentrations which mussels are not evolutionary adapted to cope with.
\end{abstract}

\section{Minireview of the Current State of the Art}

1.1. Physiological Regulation of Feeding. There is still no general agreement regarding physiological control of water pumping by suspension-feeding bivalves in response to changes in concentrations of organic and inorganic particles in the ambient water. Under optimal conditions, suspensionfeeding bivalves filter the ambient water at a maximum rate, but under suboptimal environmental conditions, including low or very high concentrations of algal cells, the valve gape is reduced, and the mantle edges retracted [1-14]. However, it has for a long time been a matter of discussion whether the filtration rate in suspension-feeding bivalves is physiologically regulated [14-23], or if it should be conceived as a basically autonomous process [2, 5, 24-27]. More recently, MacDonald and Ward [28] suggested that the blue mussel Mytilus edulis may have "adopted a "maximal clearance rate" strategy, clearing particles from suspension at a rate that is independent of seston quality."

The valve-opening response to the absence or the presence of algal cells has been thoroughly studied in
Mytilus edulis and other suspension-feeding bivalves by, for example, Jørgensen [29], Riisgård and Randløv [1], Jørgensen et al. [2], Ward and Targett [30], Riisgård [3], Clausen and Riisgård [6], Dolmer [31, 32], Newell et al. $[7,8]$, and Maire et al. [27]. Observations of the openingclosing behaviour in other bivalve species have been made by, for example, Hopkins [33], Higgins [34], Bernard [35], Ward et al. [36], Thorin et al. [37], Pascoe et al. [38], and Filgueira et al. [14]. In general, when suspension-feeding bivalves are exposed to very low algal concentrations, this eventually leads to reduced valve gape or complete closure. Thus, Riisgård et al. [9] demonstrated the regulation of the opening state and the filtration activity of M. edulis, the cockle Cardium edule, and the soft clam Mya arenaria in response to the presence and the absence of algal cells, and the authors suggested that this phenomenon represents a true physiological adaptation to situations with meagre phytoplankton suspensions. Controlled laboratory studies, using video camera recording of valve-gape responses of $M$. edulis to the presence or the absence of algal cells in the ambient water, have revealed that the critical algal 
concentration below which its closes its valves is between about 0.9 [12] and around $0.5 \mu \mathrm{g} \mathrm{chl} a \mathrm{~L}^{-1}$ [38]. However, most of the dispute about physiological regulation of the filtration rate has so far dealt with regulation of filtration rate in (very) high algal concentrations [5], and it has so far not been convincingly clarified whether the reduction in filtration rate is due to saturation of the digestive system, or whether it is the result of controlled "physiological compensations" (e.g., [15, 20, 22, 28, 39]).

Due to lack of clear definitions of "physiological regulation" of the filtration rate, Riisgård [5] suggested that valve closure and the reduction of filtration rate at high algal concentrations due to saturation of the alimentary canal should be designated "saturation reduction." High concentrations of inorganic particles (silt) may in many situations (e.g., resuspension of bottom materials in stormy weather) reduce the overall food value of suspended phytoplankton cells by a diluting effect. Above the trigger concentration for production of pseudofaeces, this dilution effect is counterbalanced by sorting by means of the labial palps as demonstrated in mussels and other suspension-feeding bivalves [40-42]. However, the role of mucus secreted by the gill epithelia in particle processing has been debated (e.g., [43]), and according to Beninger et al. [44], pseudofaeces elimination is the final rejection step in a "cascade of particle processing events which begin with capture on the gill."

Jørgensen [45] suggested that sorting of particles by the labial palps depends upon the ability simultaneously to ingest food particles in suspension and to eliminate mucus-bound particles as pseudofaeces, although it is not well understood how the concentration of particles controls the rate of mucus secretion [25]. But overloading of the ciliary gill-pump resulting in production of pseudofaeces is not likely to be directly coupled with saturation reduction.

1.2. Role of Mucus in Feeding. Normal feeding in Mytilus edulis and other suspension-feeding bivalves with laterofrontal cirri depends on the cirri-trapping principle [4648] where bands of lateral cilia produce the main water transport through interfilamentary canals of the gill while suspended particles are separated from the main currents and transferred onto the frontal surface by the action of the laterofrontal cirri. The particle capture process and the subsequent particle transport in suspension in surface currents to the mouth and down the esophagus may not involve mucus [25, 26, 45-47], but this question is debated [43, 44, 48-52]. However, higher concentrations of suspended particles in the ambient water elicit secretion of large amounts of mucus, and particles that become entangled in mucus are transported along rejection tracts to the mouth palps to be converted into pseudofaeces and ejected $[44,45,53,54]$. It has long been known (e.g., [25, $41,55])$ that particle quality is sensed on the labial palps of suspension-feeding bivalves, a process that contributes to sorting and rejecting nonfood particles. It is less well known if surface chemistry and sensing play a role in the capture process itself. Particle size affects capture efficiency, but qualitative factors may also influence particle capture, such as stickiness, electrostatic charge, and mucopolysaccharides, that is, possible interactions between the extracellular matrix of living cells and cilia and/or mucus of the bivalve gill filaments [43, 55-58].

According to Jørgensen $[25,26,45]$, mucociliary mechanisms only serve to clean the gills for excess particulate material. Undisturbed mussels produce little or no mucus, and suspended particles in amounts to "a few mg per liter" may be cleared from the water and ingested without mucus being secreted. Jørgensen [45] suggested that the degree to which particles can become concentrated in the ventral food groove is related to the critical concentration of particles in the surrounding water that can be processed without formation of pseudofaeces, and the critical concentration is of the order of $1 \mathrm{~mm}^{3} \mathrm{~L}^{-1}$. Above the critical concentration, suspended food particles in the currents that run inside the marginal grooves are transferred directly to the stomach, whereas mucus strings with imbedded particulate material are carried outside the food grooves. When the mucus strings reach the labial palps, the winding-up activity of the palps creates pseudofaeces that are dropped onto rejection tracts along the mantle edges which carry it to the posterior end where the pseudofaeces are expelled close to the exhalant jet $[25,44,45]$.

More recently, Maire et al. [27] assessed the filtration activity of the Mediterranean mussel, Mytilus galloprovincialis, under different concentrations and compositions of seston by using an automated image acquisition and analysis system which allowed for simultaneous measurements of valve gape and exhalant siphon area. Filtration rates were measured through clearance measurements whereas pumping rates were measured using hot-film probes. Immediately after the addition of algal cells (Isochrysis galbana), valve gape, exhalant siphon area, and filtration rate increased as mussels reached their maximum filtration activity. When the algal concentration was maintained above the threshold of about 800 cells $\mathrm{mL}^{-1}$ (or $0.5 \mu \mathrm{g} \mathrm{chl} a \mathrm{~L}^{-1}$ ) by successive algal additions, valve gape, exhalant siphon area, and filtration rate remained maximal. Addition of inorganic silt (kaolinite) caused no effect on exhalant siphon area, valve gape, and filtration rates for concentrations up to $30 \mathrm{mg} \mathrm{DW} \mathrm{L}^{-1}$, but pseudofaeces were produced at all tested kaolinite concentrations indicating that the mussels were efficiently sorting kaolinite from algae before ingestion. However, an extremely high kaolinite concentration of $40 \mathrm{mgDW} \mathrm{L}^{-1}$ induced a decrease in filtration rate, probably caused by "saturation of the sorting capacity of the mussels" [27]. In filtration rate experiments with $M$. edulis, Kiørboe et al. [59] found that addition of $5 \mathrm{mg}$ natural silt increased the filtration rate by about 30 to $40 \%$ as compared to rates in a pure algal suspension.

Mussels produce two kinds of faeces, known as intestinal and glandular faeces [60]. When ample food is available, the intestinal faeces constitute the vast majority of the excreted material, but, when only little food is present, it decreases considerably in amount. The intestinal faeces consist of less digested material transported directly into the hindgut, bypassing the digestive diverticula (midgut gland, e.g., [61]). The glandular faeces stem from food which gets into the digestive diverticula and so is much more thoroughly 
Table 1: Mytilus edulis. Feeding experiments (no. 1 to no. 10) conducted with a group of 20 mussels during a period of 50 days. Series of experiments were conducted at low $(\mathrm{L})$ algal concentration $(C)$ before the concentration was increased to a higher $(\mathrm{H})$ level. The mean $( \pm \mathrm{SD})$ steady-state filtration rate $(F)$ at first low algal concentration and then at subsequently higher concentration is shown along with the time $(\Delta t)$ where steady state was maintained at high concentration before incipient saturation (cf. Figure 1). Finally, the total number of algal cells (Rhodomonas salina) ingested $\left(I_{\text {tot }}=F \times C \times \Delta t\right.$ ) before saturation is shown.

\begin{tabular}{|c|c|c|c|c|c|}
\hline Exp. no. (Day) & Series & $C\left(\right.$ cells $\left.\mathrm{mL}^{-1}\right)$ & $F\left(\mathrm{~mL} \mathrm{~min}{ }^{-1}\right)$ & $\Delta t(\min )$ & $I_{\text {tot }}\left(\times 10^{6}\right.$ cells $)$ \\
\hline $1(4)$ & $1(\mathrm{~L})$ & $2,263 \pm 148$ & $14.6 \pm 1.3$ & & \\
\hline \multirow{2}{*}{$2(7)$} & $1(\mathrm{~L})$ & $1,959 \pm 60$ & $15.1 \pm 0.5$ & & \\
\hline & $2(\mathrm{~L})$ & $1,609 \pm 151$ & $17.4 \pm 1.9$ & & \\
\hline $3(8)$ & $1(\mathrm{~L})$ & $1,767 \pm 103$ & $16.7 \pm 0.9$ & & \\
\hline \multirow{2}{*}{$4(11)$} & $1(\mathrm{~L})$ & $2,061 \pm 133$ & $13.8 \pm 1.0$ & & \\
\hline & $2(\mathrm{H})$ & $8,359 \pm 144$ & $15.4 \pm 0.7$ & 96 & 12.4 \\
\hline \multirow{2}{*}{$5(15)$} & $1(\mathrm{~L})$ & $2,084 \pm 209$ & $16.3 \pm 1.7$ & & \\
\hline & $2(\mathrm{H})$ & $15,330 \pm 365$ & $16.1 \pm 0.6$ & 45 & 11.1 \\
\hline \multirow{2}{*}{$6(16)$} & $1(\mathrm{~L})$ & $2,058 \pm 146$ & $16.3 \pm 0.6$ & & \\
\hline & $2(\mathrm{H})$ & $15,921 \pm 417$ & $15.8 \pm 0.6$ & 41 & 10.3 \\
\hline \multirow{3}{*}{$7(23-24)$} & $1(\mathrm{~L})$ & $1,685 \pm 99$ & $17.9 \pm 1.3$ & & \\
\hline & $2(\mathrm{H})$ & $4,632 \pm 239$ & $20.8 \pm 1.3$ & & \\
\hline & $3(\mathrm{~L})$ & $1,685 \pm 52$ & $19.1 \pm 0.8$ & & \\
\hline \multirow{2}{*}{$8(39)$} & $1(\mathrm{~L})$ & $1,951 \pm 111$ & $20.1 \pm 1.3$ & & \\
\hline & $2(\mathrm{H})$ & $13,338 \pm 861$ & $15.5 \pm 1.3$ & 68 & 14.1 \\
\hline \multirow{2}{*}{$9(44)$} & $1(\mathrm{~L})$ & $1,783 \pm 156$ & $17.3 \pm 1.0$ & & \\
\hline & $2(\mathrm{H})$ & $9,890 \pm 81$ & $17.0 \pm 0.3$ & 54 & 9.1 \\
\hline \multirow{3}{*}{$10(50)$} & $1(\mathrm{~L})$ & $2,471 \pm 167$ & $14.1 \pm 0.6$ & & \\
\hline & $2(\mathrm{H})$ & $20,928 \pm 211$ & $16.6 \pm 0.3$ & 33 & 11.5 \\
\hline & & & & Mean \pm SD & $11.4 \pm 1.7$ \\
\hline
\end{tabular}

digested. These faeces appear as a ribbon on top of the intestinal faeces [60], and reduction in assimilation efficiency at high algal concentrations can be explained by the bypassing of the digestive gland $[54,62]$, which is an indication of incipient saturation.

\section{New Observations on Mytilus edulis}

In order to obtain more knowledge about physiological regulation of the feeding behaviour of Mytilus edulis, we focused an experimental study on (1) measurement of the filtration rate using the steady-state method at well defined algal concentrations levels that eventually lead to "saturation reduction" and (2) triggering concentrations of algal cells that result in pseudofaeces production. The main aim was to identify the upper algal concentration at which M. edulis is exploiting its filtration rate capacity over an extended period of time. By raising the algal concentration above the threshold for continuous high filtration rate, the intention was to measure the duration time before incipient saturation reduction could be observed. Further, it was of interest to evaluate if saturation and subsequently reduced filtration rate could be related to the total number of algal cells ingested previous to incipient saturation. Finally, in order to identify the critical concentration of algal cells for formation of pseudofaeces and to evaluate if algal cells bypass the digestive diverticula in $M$. edulis exposed to algal concentrations that eventually lead to saturation, we made video recordings of pseudofaeces production and microscope observations of intestinal faeces as an important part of the study reported here.

\subsection{Materials and Methods}

2.1.1. Experimental Mussels, Steady-State Method, and Experimental Approach. Blue mussels, Mytilus edulis Linnaeus, 1758, were collected in the nearby Kerteminde Bay (Stavreshoved) in August 2009. Twenty mussels of the same size $(21.53 \pm 0.21 \mathrm{~mm})$ were transferred to an aquarium with $15.8 \mathrm{~L}$ through-flowing biofiltered seawater (Figure 1). All experiments were conducted at a mean temperature of $9.1 \pm 1.6^{\circ} \mathrm{C}$ and mean salinity of $18.7 \pm 2.8$ psu.

Within a certain range of algal concentrations the blue mussel Mytilus edulis is continuously filtering with a constant rate (e.g., $[4,5])$. Therefore, when a group of blue mussels is placed in an aquarium with well-mixed seawater added algal cells (retained with 100\% efficiency by the mussels) from a culture at a constant rate $(P)$ by means of a dosing pump and, further, with a constant through-flow due to inflowing particle-free seawater at a constant rate $(F l)$, the filtration rate $(F)$ can be calculated as $[1,6]$ :

$$
F=\frac{P \times C_{a}-F_{l} \times C_{a}}{n \times C_{c}},
$$

where $n$ : number of actively filtering mussels, $C_{a}$ : algal concentration in added culture, $C_{c}$ : steady-state algal concentration in the mussel aquarium. 


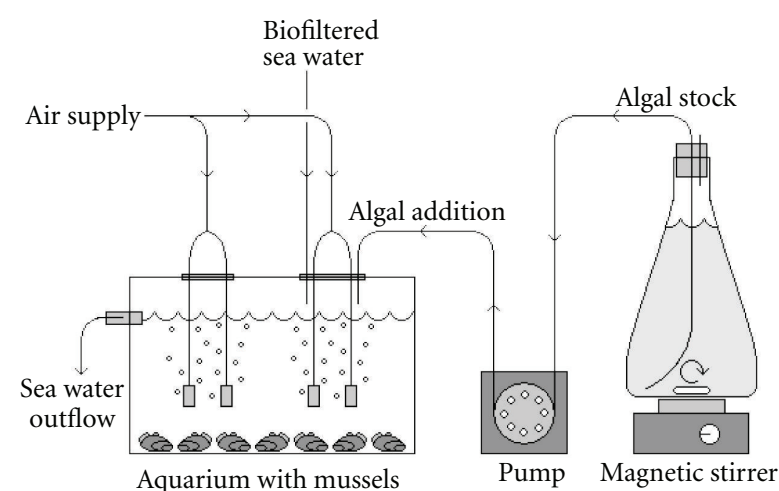

FIGURE 1: Experimental setup for performing steady-state experiments with mussels at defined algal concentration.

In order to use the steady-state method for identifying the upper threshold above which Mytilus edulis becomes saturated and subsequently reduces its filtration rate, experiments were conducted on a group of mussels. A dosing pump supplied the aquarium holding the experimental mussels with suspension of pure algae (Rhodomonas salina) which were kept homogeneous by strong mixing with 4 air stones (Figure 1). The through-flow ensured that the water in the aquarium was exchanged about once a day. The algal concentration was measured by means of an electronic particle counter (Elzone 180).

Two important prerequisites for obtaining reliable filtration rates are full mixing in the aquarium and fully open and continuously suspension-feeding mussels. However, the latter prerequisite may not be fulfilled if the algal concentration in the aquarium exceeds a certain upper algal concentration, above which the mussels become saturated and hence shut down. The present working hypothesis and the experimental approach to identify the upper concentration threshold are shown in Figure 2. The conceptual illustration shows how the lowest algal concentration above which Mytilus edulis reduces its filtration rate may be experimentally determined as done in the present work. When the mussels are exploiting their filtration rate capacity at a relatively low level ("low", about 2,000 cells $\mathrm{mL}^{-1}$ ) where a steady state can be maintained, the algal concentration is then after some time elevated ("high", $>2,000$ cells $\mathrm{mL}^{-1}$ ), and, if the new algal concentration is above an upper concentration threshold $\left(C_{u}\right)$, the mussels become saturated $(S)$ after some time $(\Delta t)$. Further, it may be hypothetically predicted that if the saturation is due to a certain total number of algal cells ingested $\left(I_{\mathrm{tot}}\right)$, then $I_{\mathrm{tot}}=F \times C \times \Delta t$, and then it may be suggested that the incipient saturation $(S)$ is reached increasingly faster at increasingly higher algal cell concentrations.

The relationship between chlorophyll $a$ concentration ( $\mu \mathrm{g} \operatorname{chl} a \mathrm{~L}^{-1}$ ) and the concentration of Rhodomonas salina $\left(C\right.$, cells $\left.\mathrm{mL}^{-1}\right)$ was chl $a=1.251 \times 10^{-3} \times C$, or $1.25 \times$ $10^{-6} \mu \mathrm{g}$ chl $a$ cell $^{-1}[6]$.

2.1.2. Measurement of Clearance Rate. In addition to values obtained from (1) during the experimental period, the



FIgURE 2: Conceptual illustration of experimental approach for using the steady-state method (Figure 1) to identify the upper algal concentration above which Mytilus edulis reduces its filtration rate. At algal concentrations above the lower threshold $\left(C_{l}\right)$, M. edulis is stimulated to open its shells and exploit its filtration rate capacity so that a steady state is maintained over an extended period of time, but, when the algal concentration is elevated above an upper concentration threshold $\left(C_{u}\right)$, the mussel becomes saturated $(s)$ after some time $(\Delta t)$ so that the mussel shuts down thus giving rise to a rapidly increasing algal concentration in the aquarium.

filtration rate was also frequently measured by means of the so-called clearance method where the filtration rate is measured as the volume of water cleared of suspended particles per unit of time. To do this, the algal dosing pump and the water through-flow to the mussel aquarium were stopped. Then the subsequent reduction in the algal cell concentration as a function of time was followed by taking water samples $(10 \mathrm{~mL})$ at $10-\mathrm{min}$ time intervals and measuring the cell concentration with an electronic particle counter (Elzone 180). Because the mussel aquarium with well-mixed seawater was added, algal Rhodomonas salina cells (mean diameter $6.9 \mu \mathrm{m}$ ) that are $100 \%$ efficiently retained by the gills of the mussels (i.e., cell diameter larger than $4 \mu \mathrm{m}$; [63]). The filtration rate $(F)$ was determined from the exponential decrease in algal concentration as a function of time using the usual clearance formula (e.g., $[25,64])$ : $F=(V / t n) \ln \left(C_{0} / C_{t}\right)=V / n \times$ slope of regression line $(b)$ in a semi-ln plot for the reduction in algal concentration with time in a well-mixed aquarium:

$$
F=\frac{V b}{n},
$$

where $C_{t}$ and $C_{0}$ are the terminal and initial concentrations of particles, $V$ is water volume in aquarium, and $n$ is number of mussels. A control experiment without mussels showed that sedimentation of algal cells was insignificant.

2.1.3. Video and Microscope Observations. Pseudofaeces expelled from Mytilus edulis of different size were observed by means of a horizontal stereo microscope with a built-in video camera (Leica MZ8) connected to a video recorder (Panasonic NV-FS200 HQ). Observations were made on individual mussels of different size. A mussel was placed in an observation aquarium $\left(12^{\circ} \mathrm{C}\right)$ in front of the stereo 
TABle 2: Mytilus edulis. Slope (b) of linear regression lines shown in Figures 4(a) and 4(b) along with the estimated individual filtration rate $(F=b \times V / n)$ according to $(2)$.

\begin{tabular}{lccccc}
\hline & Data from Figure $4(\mathrm{a})$ & & \multicolumn{3}{c}{ Data from Figure 4(b) } \\
Time period no. & $b\left(\mathrm{~h}^{-1}\right)$ & $F\left(\mathrm{~mL} \mathrm{~min}^{-1}\right)$ & Time period no. & $B\left(\mathrm{~h}^{-1}\right)$ & $F\left(\mathrm{~mL} \mathrm{~min}^{-1}\right)$ \\
\hline 1 & -1.131 & 14.9 & 1 & -0.918 & 12.1 \\
2 & -1.290 & 17.0 & 2 & -0.396 & 5.2 \\
3 & -1.320 & 17.4 & 3 & -0.726 & 9.6 \\
4 & -1.290 & 17.0 & 4 & -1.074 & 14.1 \\
& & & 5 & -1.536 & 20.2 \\
& & & 6 & -1.242 & 16.4 \\
\hline
\end{tabular}

microscope. Algal cells (Rhodomonas salina) were added to the water in the observation chamber in different initial concentrations in order to identify the threshold concentration for production of pseudofaeces, seen as threads of mucus with imbedded algae expelled in the immediate vicinity of the posterior end of the exhalant opening. Mixing was ensured by means of an air stone, and the decrease in algal concentration was measured at different time intervals along with 10 min sequences of video recordings to monitor the pseudofaeces production.

Faeces collected in complementary steady-state feeding experiments in which mussels of different size were exposed to high algal concentrations resulting in saturation and production of long faeces strings were studied with an inverted microscope (Leica DM IRB) equipped with a digital camera (CMOS camera MC13xx).

2.2. Results. The data obtained from the steady-state feeding experiments are shown in Figure 3. In all cases, a steady state was first established at a relatively low algal concentration of about 1,600 to 2,200 cells $\mathrm{mL}^{-1}$ before the algal concentration was increased by the addition of algal cells to establish a desired new algal concentration to be subsequently maintained at a new steady-state level by adjusting the algal concentration in the algal stock flask. The calculated steady-state filtration rates, cf. (1), at the low and higher algal concentration are shown in the right panel of Figure 3 and in Table 1, and examples of measurement of the filtration rate by means of the clearance method, cf. (2), are shown in Figure 4. It is seen that the filtration rate was constant and independent of algal concentration when the exposure time was shorter than the time $(\Delta t)$ it took to attain incipient saturation of the mussels. After that, the algal concentration in the mussel aquarium rapidly increased because the mussels shut down; that is, the steadystate was interrupted. When the algal dosing pump and water through-flow was then stopped and the subsequent decrease in algal cell concentration followed, the calculated filtration rate, cf. (2), was strongly reduced, both compared to similar measurements at low algal concentrations and estimated steady-state filtration rates. From Figure 4(b), it is seen that the reduced filtration rate at the high algal concentration was gradually increasing (i.e., steeper slope of regression lines), eventually to become near identical with the rate previously measured at the low algal concentration, as the mussels grazed down the algae and new additions were made. From the present findings, it can be concluded that the upper Rhodomonas salina concentration level at which the mussels do not become saturated after an extended period of time $(>3 \mathrm{~h}$ ) lies between about 5,000 (Figure 3(A7)) and 8,000 (Figure 3(A4)) cells $\mathrm{mL}^{-1}$, or, in other words, the threshold algal concentration for reduction of the filtration rate due to incipient saturation lies between about 5,000 and 8,000 cells $\mathrm{mL}^{-1}$, equivalent to 6.3 and $10.0 \mu \mathrm{g} \operatorname{chl} a \mathrm{~L}^{-1}$, respectively.

The time interval before incipient saturation $(\Delta t)$ at high algal concentration is shown in Table 1 along with the estimated total number of cells ingested before saturation. From Figure 5, it appears that $\Delta t$ decreases with increasing algal concentration. The curves in Figure 5 show the asymptotic least square fits for $\Delta t=b /\left(C-C_{0}\right)^{a}$ for $C_{0}=8000$ cells $\mathrm{mL}^{-1}$ (dotted line) leads to $b=431, a=$ $0.255\left(R^{2}=0.770\right)$ and for 5000 cells $\mathrm{mL}^{-1}$ (unbroken line), the equation leads to $b=10,484, a=0.590\left(R^{2}=0.775\right)$.

The mean Rhodomonas salina cell diameter in the mussel aquarium was measured to be $6.9 \pm 0.3 \mu \mathrm{m}$, and; hence, the mean cell volume was $174 \mu \mathrm{m}^{3}$. The mean $( \pm \mathrm{SD})$ total number of cells ingested previous to incipient saturation was found to be $I_{\text {tot }}=11.4 \pm 1.7 \times 10^{6}$ cells (Table 1 ), and; thus, the total volume of ingested cells was about $\left(11.4 \times 10^{6} \times 174=1.98 \times 10^{9} \mu \mathrm{m}^{3}=\right) 2 \mathrm{~mm}^{3}$. Obviously, the estimated value of $I_{\text {tot }}$ depends on both previous feeding condition and digestion rate, which becomes of increasingly importance with increasing $\Delta t$, but; nevertheless, it is a useful approximate measure of the maximum ingestion volume.

Figure 6 shows a time series of videographic prints of pseudofaeces being expelled from the mantle cavity close to the exhalant opening of a mussel exposed to 23,000 algal cells $\mathrm{mL}^{-1}$. By analyzing the videotape recordings, the number of pseudofaeces lumps expelled during $10 \mathrm{~min}$ intervals at known algal concentration could be semiquantified (Table 3 ). It appeared that the production of pseudofaeces started momentarily at algal concentrations above 12,000 cells $\mathrm{mL}^{-1}$ (i.e., pseudofaeces trigger concentration). It appears from Table 3 that, once the pseudofaeces production was triggered, it continued, although at a reduced rate when the algal concentration gradually, due to grazing by the mussel, came below the trigger threshold concentration. 

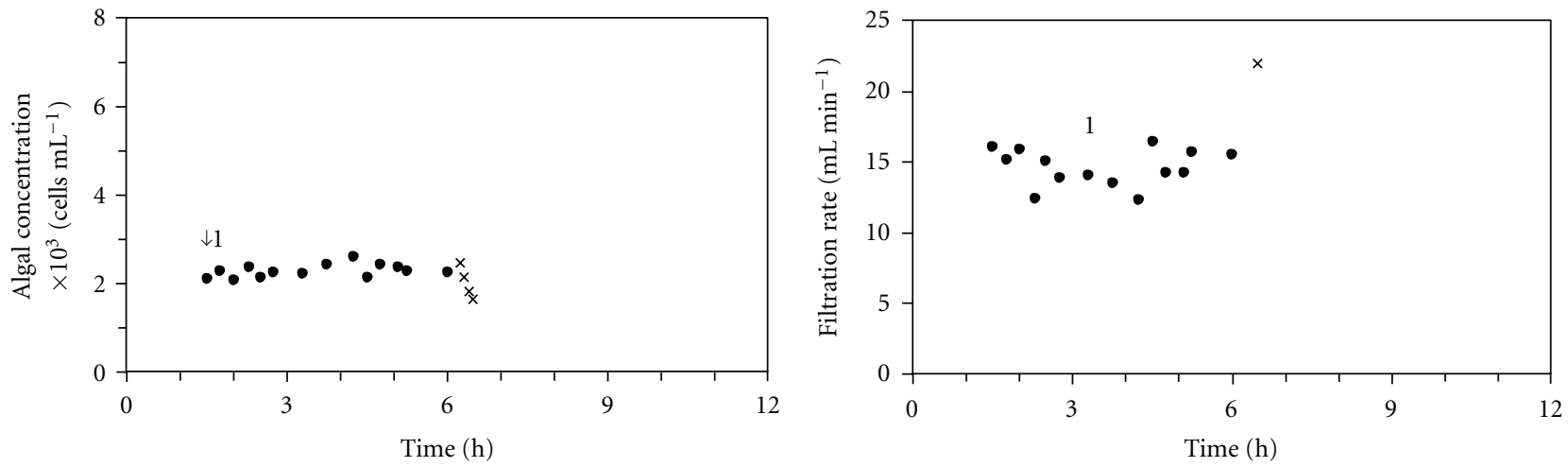

(A1)

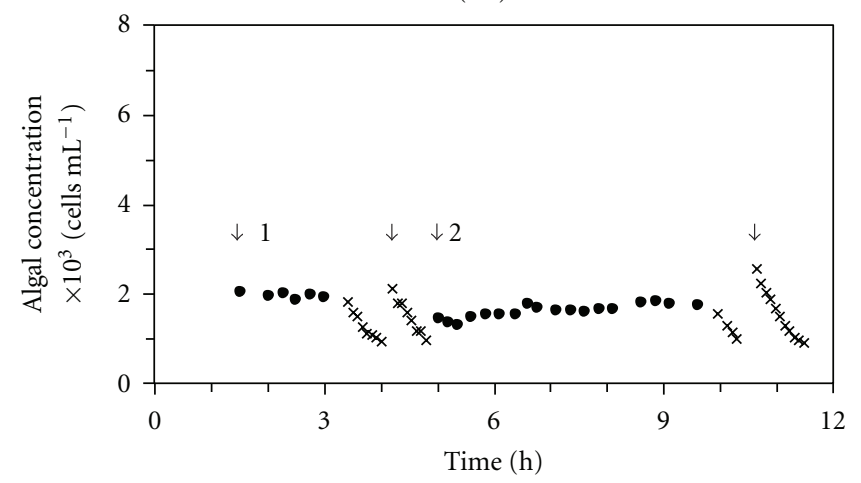

(B1)

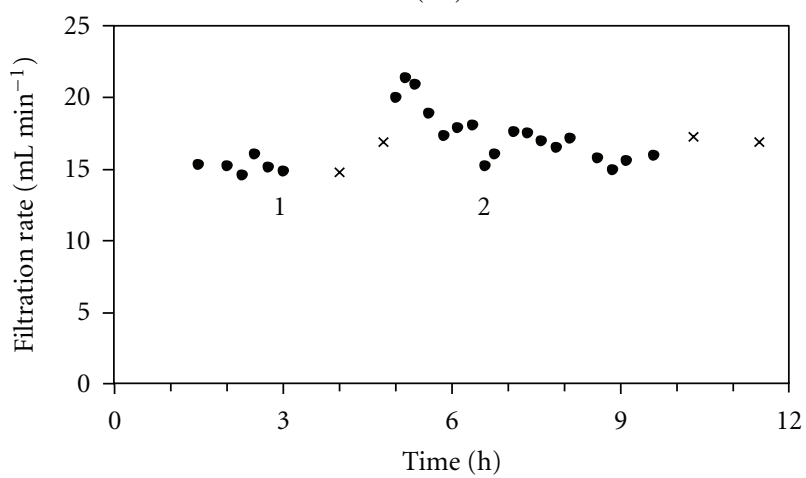

(A2)

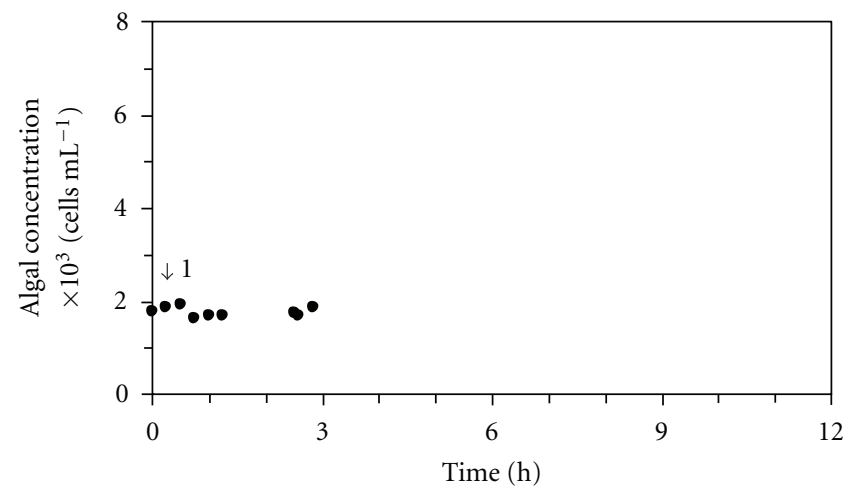

(B2)

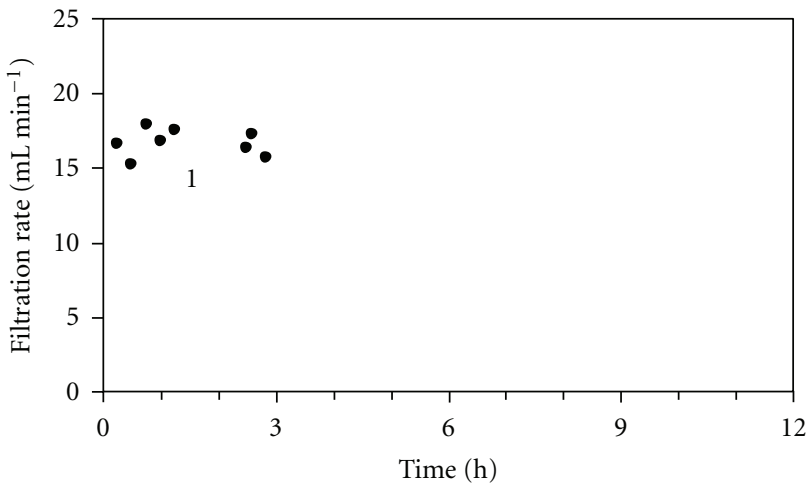

(A3)

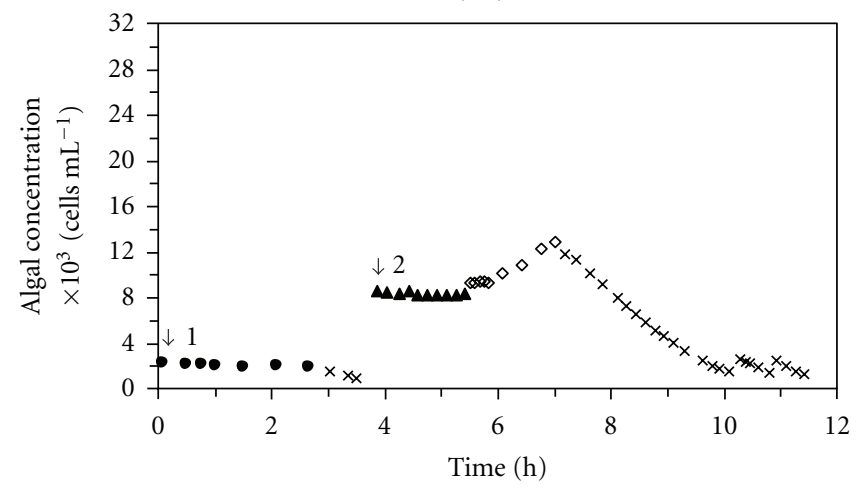

(B3)

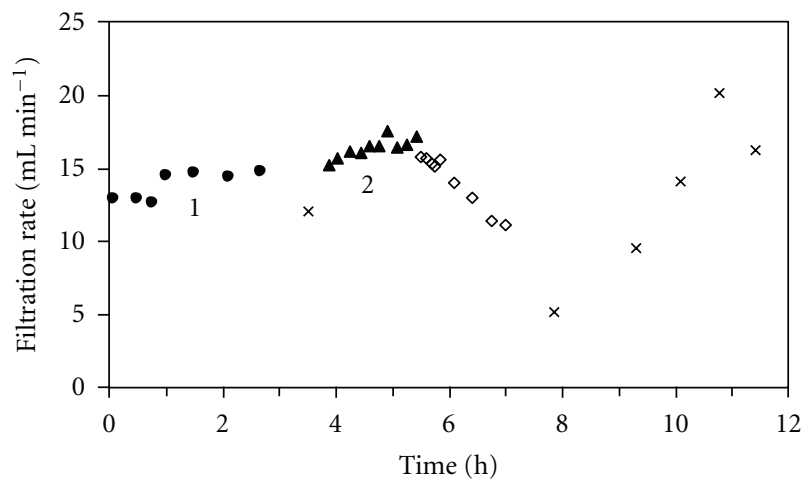

(A4)

(B4)

Figure 3: Continued. 


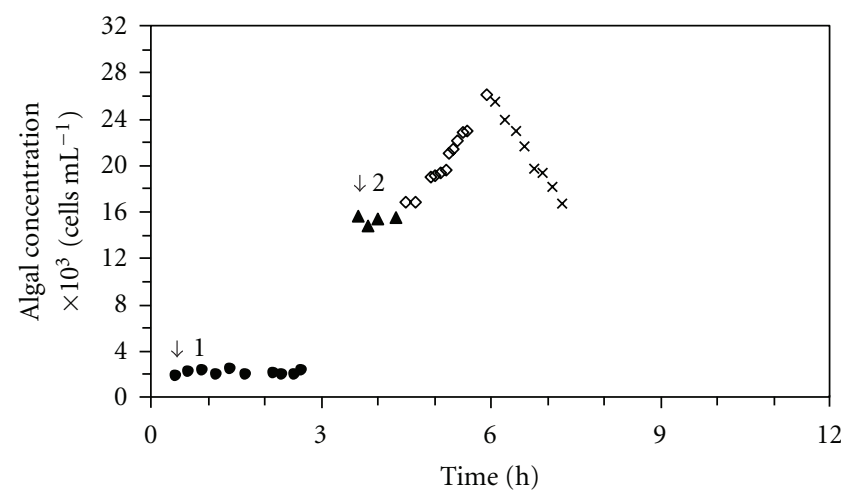

(A5)

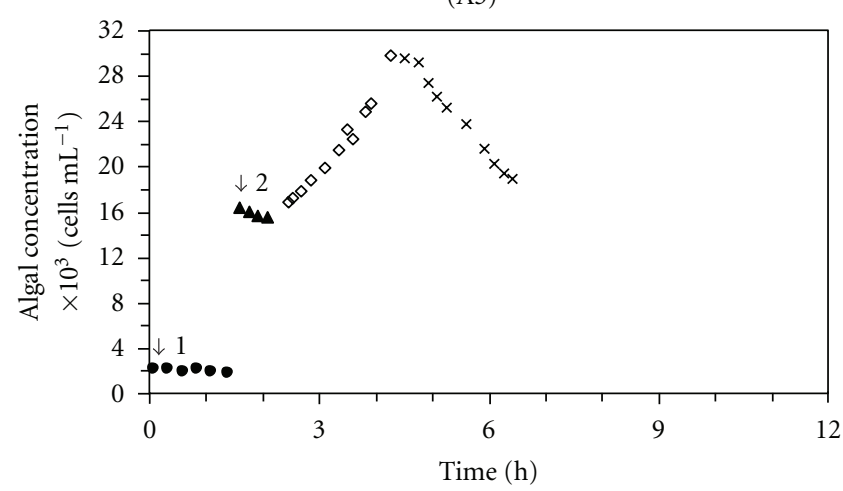

(A6)

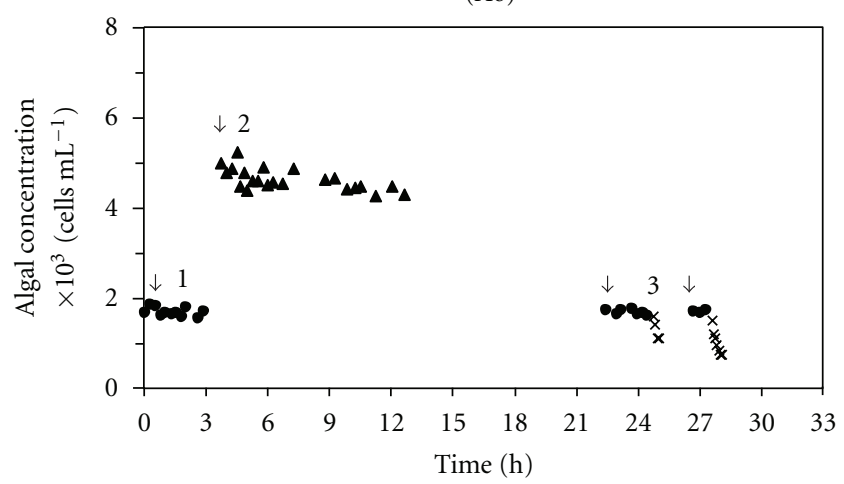

(A7)

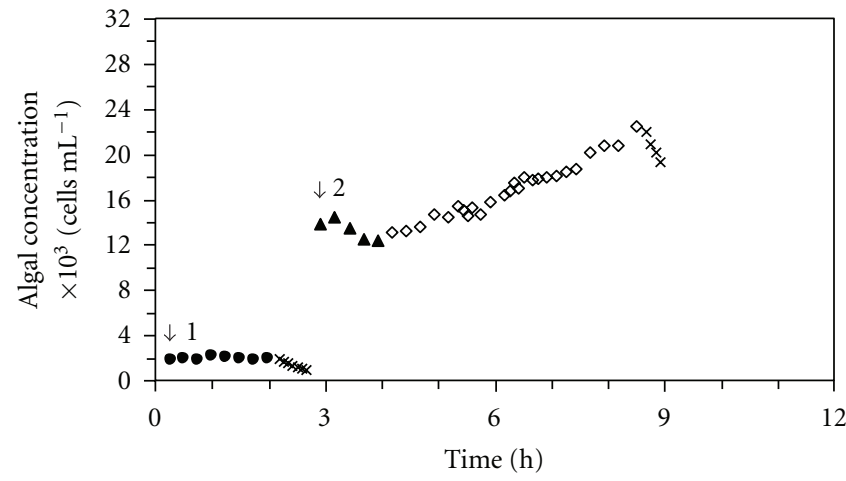

(A8)

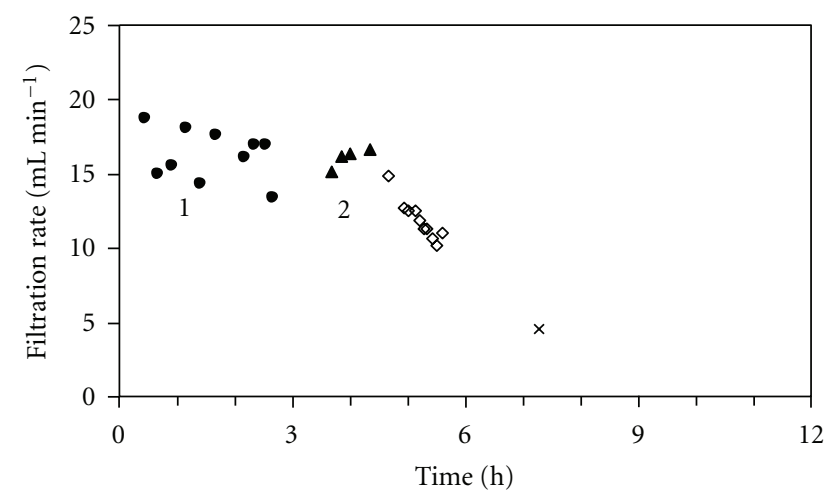

(B5)

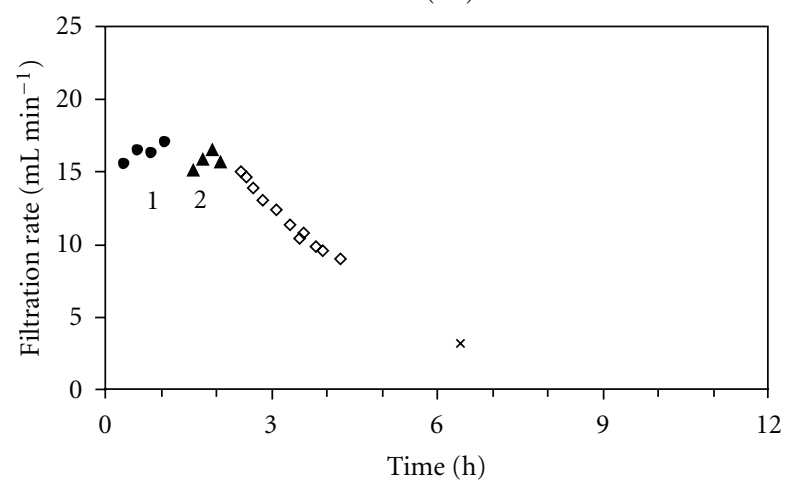

(B6)

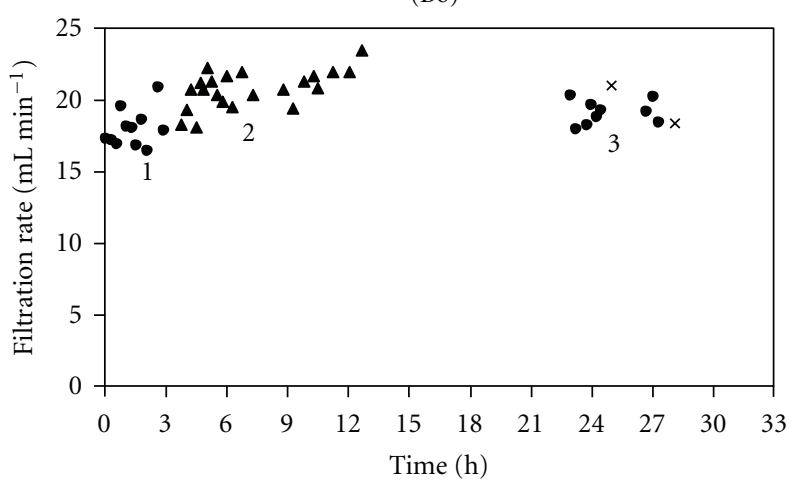

(B7)

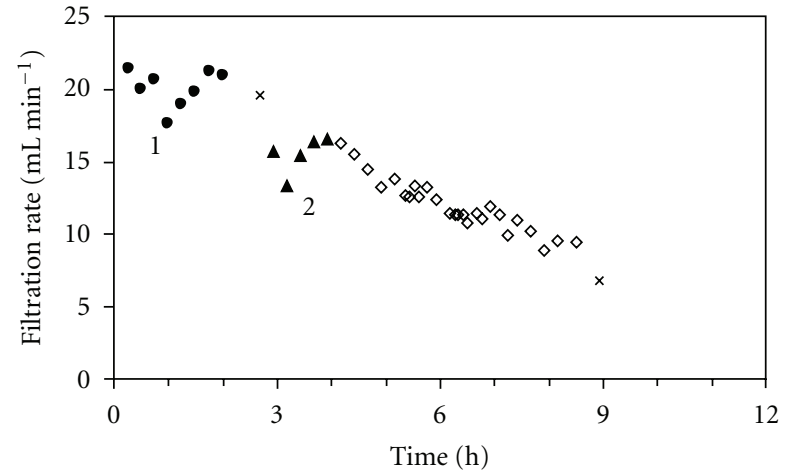

(B8)

Figure 3: Continued. 


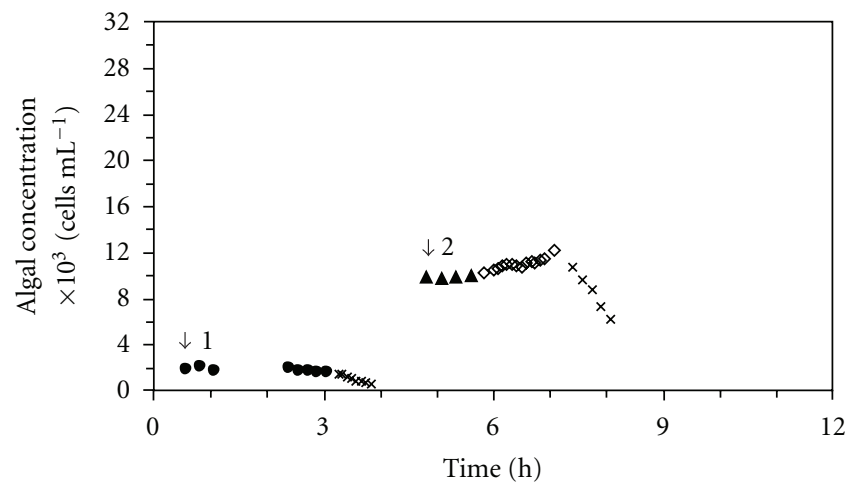

(A9)

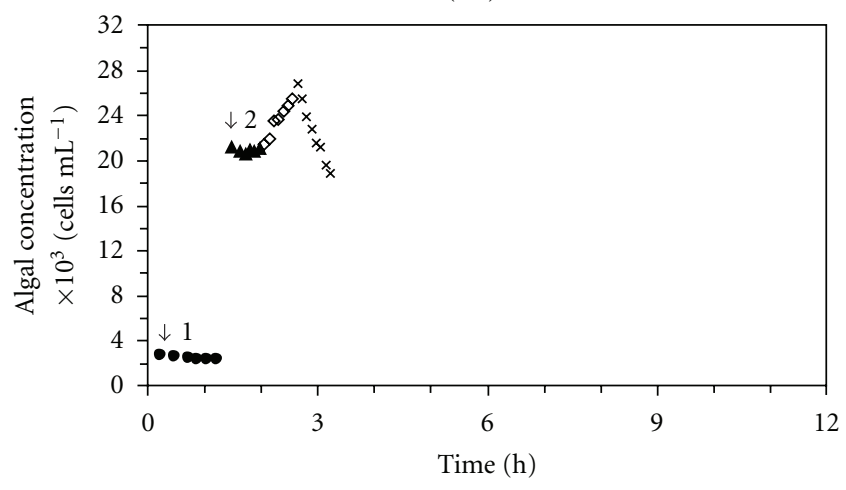

(A10)

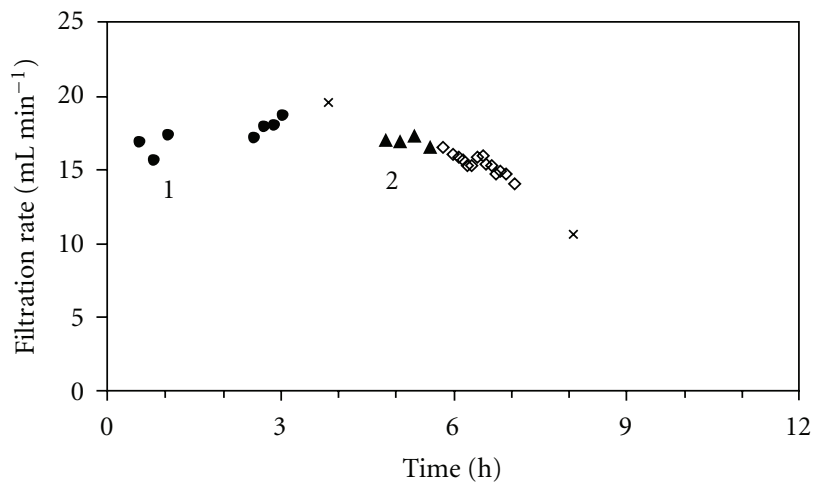

(B9)

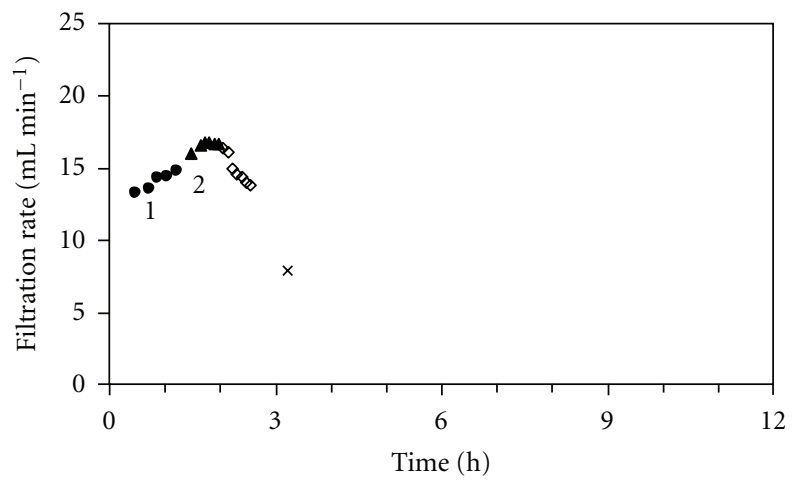

(B10)

Figure 3: Mytilus edulis. Steady-state feeding experiments (no. 1 to no. 10, Table 1) conducted with a group of 20 mussels during a period of 50 days. (A) Measured algal concentration in aquarium with mussels. Arrows indicate addition of algal cells to instantly establish a desired new algal concentration. (B) Estimated filtration rate using (1) (open and closed symbols) or using (2) (cross). Symbols: closed circle is steady state at low algal concentration (about 2,000 cells $\mathrm{mL}^{-1}$ ); closed triangle is steady state at high algal concentration $\left(>2,000\right.$ cells $\mathrm{mL}^{-1}$ ); open square is algal concentration after incipient saturation of mussels; cross is reduction in algal concentration after stoppage of algal dosing pump and water through-flow. Numbers indicate series (Table 1).

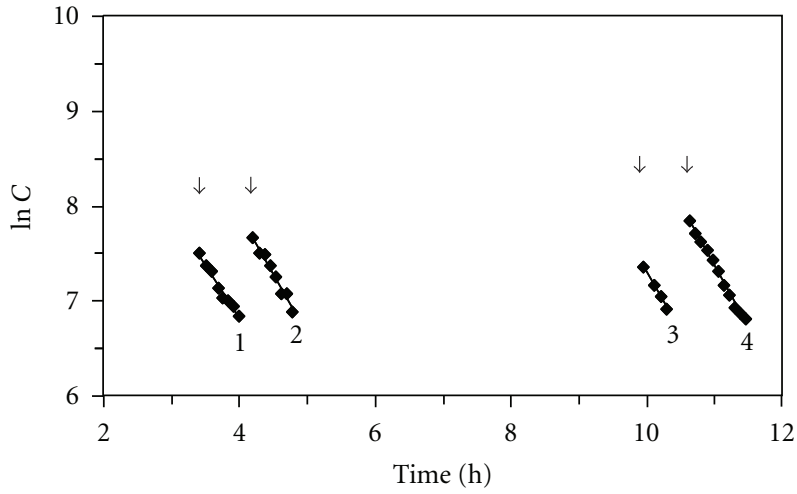

(a)

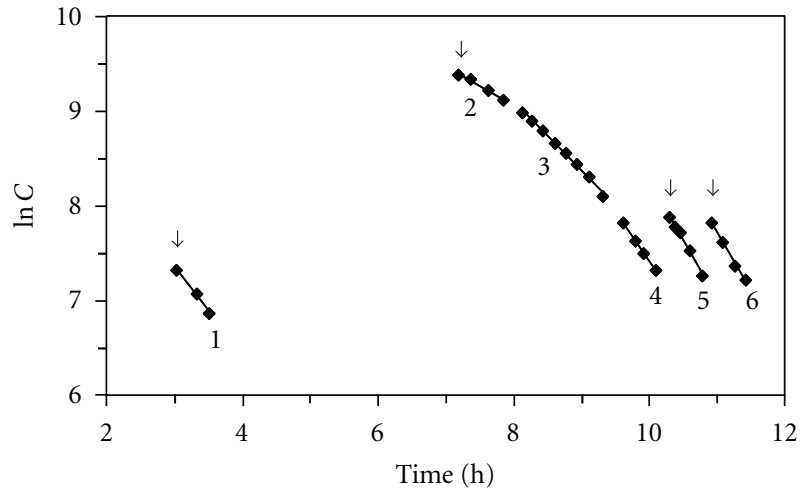

(b)

FIgUre 4: Mytilus edulis. Exponential decrease in algal cell concentration $\left(C\right.$, cells $\left.\mathrm{mL}^{-1}\right)$ as a function of time due to grazing by a group of mussels $(n=20)$ in a closed aquarium $(V=15.8 \mathrm{~L})$ with well-mixed seawater. Arrows indicate addition of algal cells. Linear regression lines for different time periods (indicated by numbers) are shown, whereas the slopes $(b)$ along with the estimated filtration rates $(F)$ are shown in Table 2. (a) Data from Figure 3, experiment no. A2; (b) data from Figure 3, experiment no. A4. 
Mussels exposed to high steady-state concentrations $\left(14,500\right.$ to 20,000 cells $\left.\mathrm{mL}^{-1}\right)$ begun after a few hours to produce long strings of faeces. The width $(W, \mu \mathrm{m})$ of the somewhat flattened faeces strings increased with the shell length $(L, \mathrm{~mm})$ of the mussels: $W=12.55 L+178.38\left(R^{2}=\right.$ $0.867, n=11)$. In all cases, microscope studies of the faeces revealed that they consisted of closely packed undigested algal cells (Figure 7).

\section{Interpretations and Basic Features of Feeding Behaviour}

The present study has demonstrated that Mytilus edulis continuously filter the ambient water at a maximum rate when fed an algal concentration between the lower critical level and the upper algal threshold concentration for incipient saturation. In this concentration interval, the mean individual filtration rate of the $21.5 \mathrm{~mm}$ shell length mussels was about $15 \mathrm{~mL} \mathrm{~min}^{-1}$ (Figure 3) which may be compared with $14.2 \mathrm{~mL} \mathrm{~min}^{-1}$ estimated from the mean shell length according to Kiørboe and Møhlenberg [41] who used the "suction method" to measure the individual filtration rate $(F$, $\left.1 \mathrm{~h}^{-1}\right)$ of $M$. edulis as a function of shell length $(L, \mathrm{~mm}): F=$ $0.0012 L^{2.14}$ (see also [4], Table 1 therein). This indicates a modest individual variability of the filtration rate within the group of mussels used in the present study, which shows that the threshold algal (Rhodomonas salina) concentration for incipient saturation reduction of the filtration rate lies between 6.3 and $10.0 \mu \mathrm{gchl} a \mathrm{~L}^{-1}$. A median value of $5.1 \mu \mathrm{g} \operatorname{chl} a \mathrm{~L}^{-1}$ has been found for Danish fjords and coastal waters [65], and; further, the mean phytoplankton biomass measured in the Great Belt (close to the collecting site of mussels used in the present work) in the period 1988-2009 has been found to be $2.8 \pm 2.1 \mu \mathrm{g} \operatorname{chl} a \mathrm{~L}^{-1}$ (Environmental Center Odense, pers. comm.). Clearly, these phytoplankton biomass levels do generally not exceed the concentration for incipient saturation reduction of the filtration rate of Mytilus edulis (see also, e.g., Stirling and Okumus [66], Figure 2(d) therein; [67], Figure 4(c) therein; [28], Table 1 therein; [68], Figure 3(a) therein) which on this background does not need to possess an ability of "physiological regulation" of the filtration rate to high algal concentrations, as also earlier emphasized by Clausen and Riisgård [6] and Riisgård [5], and for M. galloprovincialis by Maire et al. [27]. The pseudofaeces trigger concentration of about 12,000 cells $\mathrm{mL}^{-1}$, corresponding to $15.0 \mu \mathrm{gchl} a \mathrm{~L}^{-1}$, supports the view that pseudofaeces production may primarily be a cleaning mechanism for protecting the gill from being overloaded with particulate material [25-27, 41, 45], although pseudofaeces may also play a role in the sorting of edible particles from inorganic silt $[44,55,69,70]$.

The time interval before incipient saturation at high algal concentration decreases with increasing algal concentration (Figure 5), and a similar phenomenon has earlier been observed by Petersen and Riisgård [71] in the ascidian Ciona intestinalis where particle loads above a certain level result in a decrease in the ascidian's filtration rate. In the present study, the total number of cells ingested previous to incipient

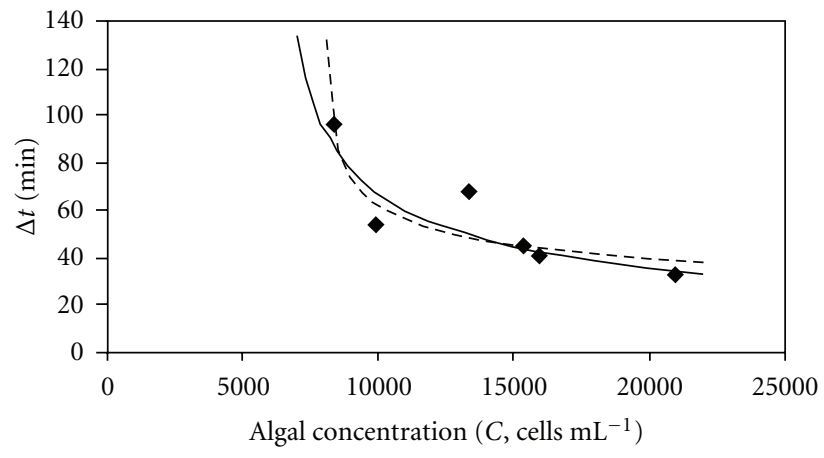

Figure 5: Mytilus edulis. Time before incipient saturation $(\Delta t)$ as a function of algal concentration $(C)$ in steady-state experiments. Lines are asymptotic least square fits for $\Delta t=b /\left(C-C_{0}\right)^{a}$ shown for $C_{0}=8000$ cells $\mathrm{mL}^{-1}$ (dotted line) and for 5000 cells $\mathrm{mL}^{-1}$ (unbroken line).

saturation reduction was about $11.4 \times 10^{6}$ cells for the small $(21.5 \mathrm{~mm})$ mussels used, but this value can of course be expected to increase considerably with increasing size, as also found for "small" and "large" ascidians by Petersen and Riisgård [71, Table 1].

The present study has demonstrated that Mytilus edulis continuously filter the ambient water at a maximum rate when fed an algal concentration between the lower critical level and the upper algal threshold concentration for incipient saturation. In an earlier study, Riisgård [3] found that the filtration capacity of $M$. edulis was exploited for at least $8 \mathrm{~h}$ between about 2,000 and 6,000 Rhodomonas baltica cells $\mathrm{mL}^{-1}$. More recent observations of $M$. edulis studied by Pascoe et al. [38] were found to be consistent with "physiological regulation" of suspension feeding bivalves "according to indicators of such regulation suggested by Riisgård [4, 5]." Thus, the algal concentration below which the filtering activity ceases was found to be $\sim 0.5 \mu \mathrm{g} \operatorname{chl} a \mathrm{~L}^{-1}$, valve closure and reduced filtration rate due to saturation were observed after feeding for $>2 \mathrm{~h}$ at $\geq 30,000$ Isochrysis galbana cells $\mathrm{mL}^{-1}\left(\sim 6 \mu \mathrm{g} \mathrm{chl} a \mathrm{~L}^{-1}\right)$, and, between these algal concentration levels, the filtration rate was maximal. In $M$. galloprovincialis, the lower trigger threshold concentration was found by Filgueira et al. [14] to be $2.08 \mu \mathrm{g} \operatorname{chl} a \mathrm{~L}^{-1}$ whereas the "threshold for saturation reduction" was about $26.91 \mathrm{chl} a \mathrm{~L}^{-1}$, and, between these algal concentrations, the filtration rate remained high and constant. Although there is still no general agreement regarding physiological control of water pumping in response to (very) high concentrations of particles in the ambient water, present consensus tends to be that the filtration rate is high and constant, that is, basically autonomous, between a lower critical level and an upper algal threshold. However, it remains to be clarified if reduced filtration rate at high algal concentrations is caused by physiological regulation (supporting maximum assimilation and growth) or overloading (adversely affecting food uptake and growth).

The microscope studies of faeces produced by saturated mussels revealed that they consisted of closely packed undigested algal cells, and this may not support the theory 


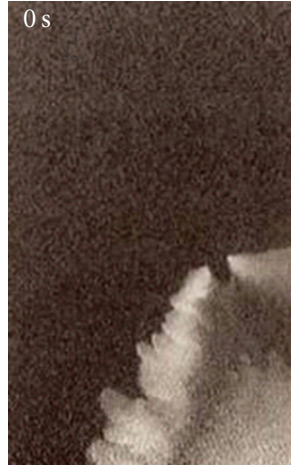

(a)

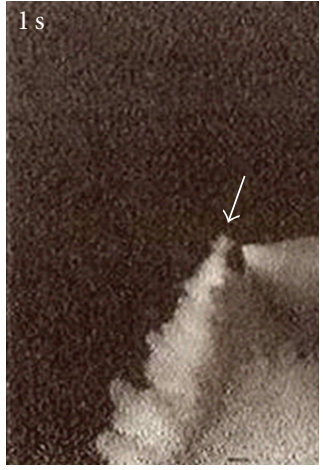

(b)

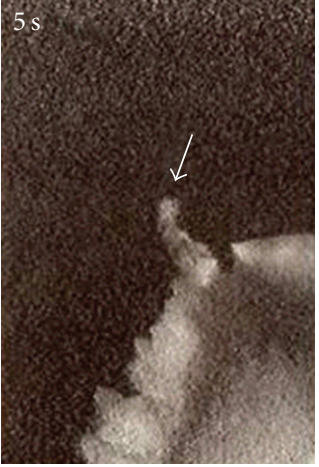

(c)



(d)

Figure 6: Mytilus edulis. Time series of videographic prints ( 0 to $6 \mathrm{~s}$ ) showing pseudofaeces (small arrow) being expelled from the mantle cavity close to the exhalant opening of a $34.3 \mathrm{~mm}$ shell length mussel exposed to 23,000 algal (Rhodomonas salina) cells $\mathrm{mL}^{-1}$. Inhalant (inh) and exhalant (exh) water indicated by dotted arrow.

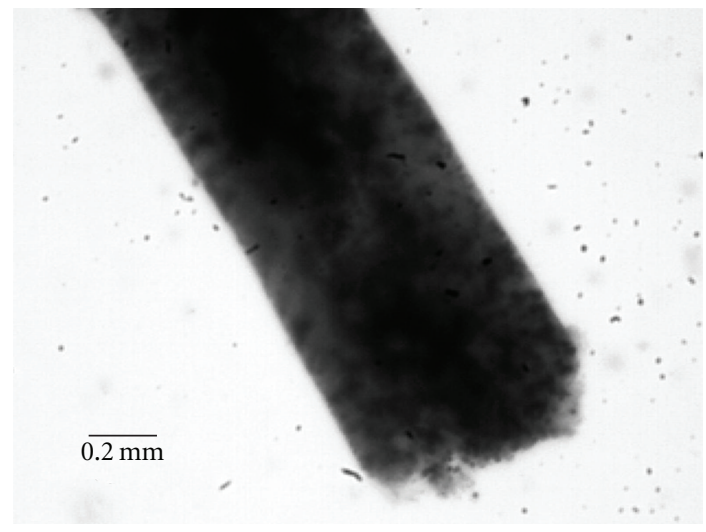

(a)

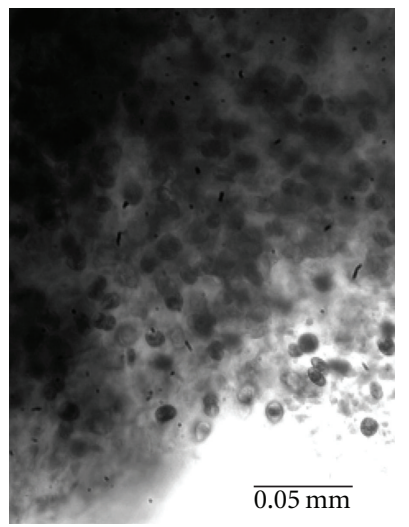

(b)

Figure 7: Mytilus edulis. (a) String of faeces from a $36.6 \mathrm{~mm}$ shell length mussel fed algal cells (Rhodomonas salina) at a concentration of 20,000 cells $\mathrm{mL}^{-1}$. (b) Closeup of faeces revealing closely packed undigested algal cells.

of a feed-back controlled physiological regulation of the ingestion rate. Thus, although the filtration rate in saturated mussels (and ascidians) may be reduced due to a physiological response this does not necessarily mean that the filtration rate is adjusted by a physiological regulatory mechanism to ensure a constant assimilation rate (cf. [72, Figure 8]) or a constant ingestion rate [73, Figures 4.8]. Rather, undigested algal cells in the faeces (Figure 7) along with the production of pseudofaeces indicate severe overloading of both the digestive system and the ciliary-gill pump caused by the abnormally high algal concentrations which suspension feeding mussels are not evolutionary adapted to cope with. In other situations, with normal algal concentrations but high silt concentrations, this may not lead to saturation of the digestive system and subsequently reduced filtration rate although the simultaneous pseudofaeces production may be high $[6,59]$. Jørgensen [45] suggested that the pseudofaces trigger concentration is about $1 \mathrm{~mm}^{3} \mathrm{~L}^{-1}$, equivalent to 5800 Rhodonomas salina cells which is somewhat lower than that found in the present study where the trigger concentration was determined to be about 12,000 cells $\mathrm{mL}^{-1}$, which also result in saturation reduction of the filtration rate although the two phenomena are not directly coupled.

In nature, many factors may influence the filtration rate of bivalves, and feeding under laboratory conditions may not accurately reflect in situ filtration where a wide spectrum of changing environmental factors may influence the feeding behaviour (e.g., [28]). Nevertheless, the present study is believed to reflect important basic features of mussels' feeding behaviour in nature where phytoplankton is the main source of nutrition. Thus, among the many parameters that may affect the in situ feeding behaviour, the phytoplankton biomass (expressed as the chl $a$ concentration) seems to be the most important although, for example, high concentrations of silt/seston leading to preingestive rejection/pseudofaeces production may also affect the feeding of mussels in many estuaries and exposed coastal waters. 
TABle 3: Mytilus edulis. Pseudofaeces production by mussels exposed to different initial algal (Rhodomonas salina) concentrations. Opening degree symbols: 3 : fully open, 2 : reduced, 1 : nearly closed. No observation $=$ no. Filtration rate $(F)$ using $(2) .{ }^{*}$ New addition of algae.

\begin{tabular}{|c|c|c|c|c|c|c|}
\hline Series no. & Shell length $(\mathrm{mm})$ & Time $(\min )$ & $C\left(\right.$ cells $\left.\mathrm{mL}^{-1}\right)$ & Pseudofaeces (no. per $10 \mathrm{~min}$ ) & Opening degree & $F\left(\mathrm{~mL} \mathrm{~min}^{-1}\right)$ \\
\hline \multirow{3}{*}{1} & \multirow{3}{*}{34.3} & 0 & 23,500 & 22 & no & \multirow{3}{*}{25.5} \\
\hline & & 52 & 13,700 & 46 & 3 & \\
\hline & & 112 & 9,100 & 22 & 2 & \\
\hline \multirow{6}{*}{2} & \multirow{6}{*}{34.3} & 0 & 16,700 & 26 & 2 & \multirow{3}{*}{23.4} \\
\hline & & 50 & 10,200 & 18 & 1 & \\
\hline & & 118 & 8,900 & no & no & \\
\hline & & $120^{*}$ & 10,000 & 34 & no & \multirow{3}{*}{31.5} \\
\hline & & 170 & 5,800 & 19 & 2 & \\
\hline & & 235 & 4,000 & 9 & 2 & \\
\hline \multirow{3}{*}{3} & \multirow{3}{*}{34.3} & 0 & 10,000 & 0 & 1 & \multirow{3}{*}{15.3} \\
\hline & & 68 & 4,900 & 0 & 3 & \\
\hline & & 127 & 2,600 & 0 & 3 & \\
\hline \multirow{3}{*}{4} & \multirow{3}{*}{36.8} & 0 & 19,200 & 17 & 1 & \multirow{3}{*}{66.3} \\
\hline & & 30 & 9,100 & 4 & 3 & \\
\hline & & 90 & 2,600 & 0 & 3 & \\
\hline \multirow{4}{*}{5} & \multirow{4}{*}{36.8} & 0 & 12,900 & 8 & 2 & \multirow{4}{*}{51.6} \\
\hline & & 8 & 12,700 & 26 & 3 & \\
\hline & & 42 & 6,000 & 1 & 3 & \\
\hline & & 90 & 2,700 & 0 & 3 & \\
\hline \multirow{6}{*}{6} & \multirow{6}{*}{36.8} & 0 & 14,600 & 6 & 2 & \multirow{3}{*}{50.4} \\
\hline & & 40 & 9,400 & 4 & 3 & \\
\hline & & 85 & 3,500 & 0 & 3 & \\
\hline & & $225^{*}$ & 12,100 & 0 & 3 & \multirow{3}{*}{60.3} \\
\hline & & 300 & 5,100 & 0 & 3 & \\
\hline & & 342 & 1,000 & 0 & 3 & \\
\hline \multirow{6}{*}{7} & \multirow{6}{*}{63.7} & 0 & 21,500 & 42 & 2 & \multirow{3}{*}{67.8} \\
\hline & & 43 & 8,500 & 42 & 2 & \\
\hline & & 93 & 2,600 & 26 & 2 & \\
\hline & & $180^{*}$ & 10,600 & 41 & 1 & \multirow{3}{*}{56.7} \\
\hline & & 227 & 2,400 & 14 & 3 & \\
\hline & & 285 & 1,400 & 5 & 2 & \\
\hline
\end{tabular}

\section{Acknowledgments}

This work formed part of the MarBioShell project supported by the Danish Agency for Science, Technology and Innovation for the period January 2008 to December 2012. Thanks are due to Professors P. S. Larsen, P. G. Beninger, and B. A. MacDonald for constructive comments on the manuscript.

\section{References}

[1] H. U. Riisgård and A. Randløv, "Energy budgest, growth and filtration rates in Mytilus edulis at different algal concentrations," Marine Biology, vol. 61, no. 2-3, pp. 227-234, 1981.

[2] C. B. Jørgensen, P. S. Larsen, F. Møhlenberg, and H. U. Riisgård, "The bivalve pump: properties and modelling," Marine Ecology Progress Series, vol. 45, pp. 205-216, 1988.

[3] H. U. Riisgård, "Filtration rate and growth in the blue mussel, Mytilus edulis Linnaeus, 1758: dependence on algal concentration," Journal of Shellfish Research, vol. 10, pp. 2935, 1991.

[4] H. U. Riisgård, "On measurement of filtration rates in bivalves - the stony road to reliable data: review and interpretation," Marine Ecology Progress Series, vol. 211, pp. 275-291, 2001.

[5] H. U. Riisgård, "Physiological regulation versus autonomous filtration in filter-feeding bivalves: starting points for progress," Ophelia, vol. 54, no. 3, pp. 193-209, 2001.

[6] I. Clausen and H. U. Riisgård, "Growth, filtration and respiration in the mussel Mytilus edulis: no evidence for physiological regulation of the filter-pump to nutritional needs," Marine Ecology Progress Series, vol. 141, no. 1-3, pp. 37-45, 1996.

[7] C. R. Newell, D. E. Campbell, and S. C. Gallagher, "Development of the mussel aquaculture lease site model MUSMOD: a field program to calibrate model formulations," Journal of Experimental Marine Biology and Ecology, vol. 219, no. 1-2, pp. 143-169, 1998.

[8] C. R. Newell, D. J. Wildish, and B. A. MacDonald, "The effects of velocity and seston concentration on the exhalant 
siphon area, valve gape and filtration rate of the mussel Mytilus edulis," Journal of Experimental Marine Biology and Ecology, vol. 262, no. 1, pp. 91-111, 2001.

[9] H. U. Riisgård, C. Kittner, and D. F. Seerup, "Regulation of opening state and filtration rate in filter-feeding bivalves (Cardium edule, Mytilus edulis, Mya arenaria) in response to low algal concentration," Journal of Experimental Marine Biology and Ecology, vol. 284, no. 1-2, pp. 105-127, 2003.

[10] L. A. van Duren, P. M. J. Herman, A. J. J. Sandee, and C. H. R. Heip, "Effects of mussel filtering activity on boundary layer structure," Journal of Sea Research, vol. 55, no. 1, pp. 3-14, 2005.

[11] J. Lassen, M. Kortegård, H. U. Riisgård, M. Friedrichs, G. Graf, and P. S. Larsen, "Down-mixing of phytoplankton above filter-feeding mussels-interplay between water flow and biomixing," Marine Ecology Progress Series, vol. 314, pp. 77-88, 2006.

[12] H. U. Riisgård, J. Lassen, and C. Kittner, "Valve-gape response times in mussels (Mytilus edulis)—effects of laboratory preceding-feeding conditions and in situ tidally induced variation in phytoplankton biomass," Journal of Shellfish Research, vol. 25, no. 3, pp. 901-911, 2006.

[13] B. A. Macdonald, S. M. C. Robinson, and K. A. Barrington, "Evaluating the use of exhalent siphon area in estimating feeding activity of blue mussels, Mytilus edulis," Journal of Shellfish Research, vol. 28, no. 2, pp. 289-297, 2009.

[14] R. Filgueira, M. J. Fernández-Reiriz, and U. Labarta, "Clearance rate of the mussel Mytilus galloprovincialis. I. Response to extreme chlorophyll ranges," Ciencias Marinas, vol. 35, no. 4, pp. 405-417, 2009.

[15] B. L. Bayne, J. I. P. Iglesias, A. J. S. Hawkins, E. Navarro, M. Heral, and J. M. Deslous-Paoli, "Feeding behaviour of the mussel, Mytilus edulis: responses to variations in quantity and organic content of the seston," Journal of the Marine Biological Association of the United Kingdom, vol. 73, no. 4, pp. 813-829, 1993.

[16] B. L. Bayne, "Feeding physiology of bivalves: time-dependent and compensation for changes in food availability," in Bivalve Filter Feeders, R. F. Dame, Ed., vol. G33 of NATO ASI Series, pp. 1-24, Springer, Heidelberg, Germany, 1993.

[17] B. L. Bayne, "The physiology of suspension feeding by bivalve molluscs: an introduction to the Plymouth "TROPHEE" workshop," Journal of Experimental Marine Biology and Ecology, vol. 219, no. 1-2, pp. 1-19, 1998.

[18] B. L. Bayne, "Physiological components of growth differences between individual oysters (Crassostrea gigas) and a comparison with Saccostrea commercialis," Physiological and Biochemical Zoology, vol. 72, no. 6, pp. 705-713, 1999.

[19] B. L. Bayne, "Relations between variable rates of growth, metabolic costs and growth efficiencies in individual Sydney rock oysters (Saccostrea commercialis)," Journal of Experimental Marine Biology and Ecology, vol. 251, no. 2, pp. 185-203, 2000.

[20] R. I. Willows, "Optimal digestive investment: a model for filter feeders experiencing variable diets," Limnology \& Oceanography, vol. 37, no. 4, pp. 829-847, 1992.

[21] A. J. S. Hawkins, M. R. James, R. W. Hickman, S. Hatton, and M. Weatherhead, "Modelling of suspension-feeding and growth in the green-lipped mussel Perna canaliculus exposed to natural and experimental variations of seston availability in the Marlborough Sounds, New Zealand," Marine Ecology Progress Series, vol. 191, pp. 217-232, 1999.

[22] P. J. Cranford and P. S. Hill, "Seasonal variation in food utilization by the suspension-feeding bivalve molluscs Mytilus edulis and Placopecten magellanicus," Marine Ecology Progress Series, vol. 190, pp. 223-239, 1999.

[23] M. B. Urrutia, E. Navarro, I. Ibarrola, and J. I. P. Iglesias, "Preingestive selection processes in the cockle Cerastoderma edule: mucus production related to rejection of pseudofaeces," Marine Ecology Progress Series, vol. 209, pp. 177-187, 2001.

[24] C. B. Jørgensen, P. Famme, H. S. Kristensen, P. S. Larsen, F. Møhlenberg, and H. U. Riisgård, "The bivalve pump," Marine Ecology Progress Series, vol. 34, pp. 69-77, 1986.

[25] C. B. Jørgensen, Bivalve Filter Feeding: Hydrodynamics, Bioenergetics, Physiology and Ecology, Olsen \& Olsen, Fredensborg, Denmark, 1990.

[26] C. B. Jørgensen, "Bivalve filter feeding revisited," Marine Ecology Progress Series, vol. 142, no. 1-3, pp. 287-302, 1996.

[27] O. Maire, J. M. Amouroux, J. C. Duchêne, and A. Grémare, "Relationship between filtration activity and food availability in the Mediterranean mussel Mytilus galloprovincialis," Marine Biology, vol. 152, no. 6, pp. 1293-1307, 2007.

[28] B. A. MacDonald and J. E. Ward, "Feeding activity of scallops and mussels measured simultaneously in the field: repeated measures sampling and implications for modelling," Journal of Experimental Marine Biology and Ecology, vol. 371, no. 1, pp. 42-50, 2009.

[29] C. B. Jørgensen, "On gill function in the mussel Mytilus edulis L," Ophelia, vol. 13, pp. 187-232, 1975.

[30] J. E. Ward and N. M. Targett, "Influence of marine microalgal metabolites on the feeding behavior of the blue mussel Mytilus edulis," Marine Biology, vol. 101, no. 3, pp. 313-321, 1989.

[31] P. Dolmer, "Algal concentration profiles above mussel beds," Journal of Sea Research, vol. 43, no. 2, pp. 113-119, 2000.

[32] P. Dolmer, "Feeding activity of mussels Mytilus edulis related to near-bed currents and phytoplankton biomass," Journal of Sea Research, vol. 44, no. 3-4, pp. 221-231, 2000.

[33] A. E. Hopkins, "Experiments on the feeding behavior of the oyster, Ostera gigas," Journal of Experimental Zoology, vol. 64, no. 3, pp. 469-494, 1933.

[34] P. J. Higgins, "Effects of food availability on the valve movements and feeding behavior of juvenile Crassostrea virginica (Gmelin). I. Valve movements and periodic activity," Journal of Experimental Marine Biology and Ecology, vol. 45, no. 2, pp. 229-244, 1980.

[35] F. R. Bernard, Physiology and the Mariculture of Some Northeastern Pacific Bivalve Molluscs, Canadian Special Publication of Fisheries and Aquatic Sciences no. 63, 1983.

[36] J. E. Ward, H. K. Gassell, and B. A. MacDonald, "Chemorecption in the sea scallop Placopecten magellanicus (Gmelin). I. Stimulatory effects of phytoplankton metabolites on clearance and ingestion rates," Journal of Experimental Marine Biology and Ecology, vol. 163, pp. 235-250, 1992.

[37] S. Thorin, H. Bourdages, and B. Vincent, "Study of siphon activity in Mya arenaria (L.) in the intertidal zone by means of an underwater video camera," Journal of Experimental Marine Biology and Ecology, vol. 224, no. 2, pp. 205-224, 1998.

[38] P. L. Pascoe, H. E. Parry, and A. J. S. Hawkins, "Observations on the measurement and interpretation of clearance rate variations in suspension-feeding bivalve shellfish," Aquatic Biology, vol. 6, no. 1-3, pp. 181-190, 2009.

[39] H. U. Riisgård and P. S. Larsen, "Comparative ecophysiology of active zoobenthic filter feeding, essence of current knowledge," Journal of Sea Research, vol. 44, no. 3-4, pp. 169-193, 2000.

[40] T. Kiørboe, F. Møhlenberg, and O. Nøhr, "Feeding, particle selection and carbon absorption in Mytilus edulis in different mixtures of algae and resuspended bottom material," Ophelia, vol. 19, pp. 193-205, 1980. 
[41] T. Kiørboe and F. Møhlenberg, "Particle selection in suspension-feeding bivalves," Marine Ecology Progress Series, vol. 5, pp. 291-296, 1981.

[42] R. I. E. Newell and S. J. Jordan, "Preferential ingestion of organic material by the American oyster Crassostrea virginica," Marine Ecology Progress Series, vol. 13, pp. 47-53, 1983.

[43] P. G. Beninger and S. D. St-Jean, "The role of mucus in particle processing by suspension-feeding marine bivalves: unifying principles," Marine Biology, vol. 129, no. 2, pp. 389-397, 1997.

[44] P. G. Beninger, A. Veniot, and Y. Poussart, "Principles of pseudofeces rejection on the bivalve mantle: integration in particle processing," Marine Ecology Progress Series, vol. 178, pp. 259-269, 1999.

[45] C. B. Jørgensen, "Feeding and cleaning mechanisms in the suspension feeding bivalve Mytilus edulis," Marine Biology, vol. 65 , no. 2, pp. 159-163, 1981.

[46] N. F. Nielsen, P. S. Larsen, H. U. Riisgård, and C. B. Jørgensen, "Fluid motion and particle retention in the gill of Mytilus edulis: video recordings and numerical modelling," Marine Biology, vol. 116, pp. 61-71, 1993.

[47] H. U. Riisgård, P. S. Larsen, and N. F. Nielsen, "Particle capture in the mussel Mytilus edulis: the role of latero-frontal cirri," Marine Biology, vol. 127, no. 2, pp. 259-266, 1996.

[48] H. U. Riisgård and P. S. Larsen, "Particle capture mechanisms in suspension-feeding invertebrates," Marine Ecology Progress Series, vol. 418, pp. 255-293, 2010.

[49] P. G. Beninger, M. Le Pennec, and A. Donval, "Mode of particle ingestion in five species of suspension-feeding bivalve molluscs," Marine Biology, vol. 108, no. 2, pp. 255-261, 1991.

[50] J. E. Ward, B. A. Macdonald, R. J. Thompson, and P. G. Beninger, "Mechanisms of suspension feeding in bivalves: resolution of current controversies by means of endoscopy," Limnology \& Oceanography, vol. 38, no. 2, pp. 265-272, 1993.

[51] C. B. Jørgensen, "A comment on "Mechanisms of suspension feeding in bivalves: resolution of current controversies by means of endoscopy" (Ward et al.)," Limnology \& Oceanography, vol. 38, no. 2, p. 466, 1993.

[52] J. E. Ward, B. A. MacDonald, R. J. Thompson, and P. G. Beninger, "The role of mucus in bivalve feeding-a reply to the comment by Jørgensen," Limnology \& Oceanography, vol. 39, no. 2, p. 467, 1993.

[53] R. L. Foster-Smith, "The function of the pallial organs of bivalves in controlling ingestion," Journal of Molluscan Studies, vol. 44, pp. 83-99, 1978.

[54] J. Widdows, P. Fieth, and C. M. Worrall, "Relationships between seston, available food and feeding activity in the common mussel Mytilus edulis," Marine Biology, vol. 50, no. 3, pp. 195-207, 1979.

[55] P. G. Beninger, A. Valdizan, B. Cognie, F. Guiheneuf, and P. Decottignies, "Wanted: alive and not dead: functioning diatom status is a quality cue for the suspension-feeder Crassostrea gigas," Journal of Plankton Research, vol. 30, no. 6, pp. 689-697, 2008.

[56] J. E. Ward and S. E. Shumway, "Separating the grain from the chaff: particle selection in suspension- and deposit-feeding bivalves," Journal of Experimental Marine Biology and Ecology, vol. 300, no. 1-2, pp. 83-130, 2004.

[57] J. E. Ward, J. S. Levinton, S. E. Shumway, and T. Cucci, "Particle sorting in bivalves: in vivo determination of the pallial organs of selection," Marine Biology, vol. 131, no. 2, pp. 283-292, 1998.

[58] P. E. Espinosa, M. Perrigault, S. E. Shumway, J. E. Ward, and B. Allam, "Implication of lectins associated with feeding organs in particle selection in the oyster Crassostrea virginica," Biological Bulletin, vol. 217, no. 2, pp. 130-141, 2009.

[59] T. Kiørboe, F. Møhlenberg, and O. Nøhr, "Effect of suspended bottom material on growth and energetics in Mytilus edulis," Marine Biology, vol. 61, no. 4, pp. 283-288, 1981.

[60] P. B. van Weel, "The comparative physiology of digestion in molluscs," Integrative \& Comparative Biology, vol. 1, no. 2, pp. 245-252, 1961.

[61] G. Owen, "Observations on the stomach and digestive diverticula of the Lamelibranchia. I. The Anisomyaria and Eulamellibranchia," Quarterly Journal of Microscopical Science, vol. 96, pp. 517-537, 1955.

[62] R. J. Thompson and B. L. Bayne, "Active metabolism associated with feeding in the mussel Mytilus edulis L," Journal of Experimental Marine Biology and Ecology, vol. 9, no. 1, pp. 111-124, 1972.

[63] F. Møhlenberg and H. U. Riisgård, "Efficiency of particle retention in 13 species of suspension-feeding bivalves," Ophelia, vol. 17, pp. 139-246, 1978.

[64] J. Coughlan, "The estimation of filtering rate from the clearance of suspensions," Marine Biology, vol. 2, no. 4, pp. 356-358, 1969.

[65] K. Sand-Jensen, S. L. Nielsen, J. Borum, and O. GeertzHansen, Phytoplankton and Macrophyte Development in Danish Coastal Waters, Havforskning fra Miljøstyrelsen nr. 30, Miljøministeriet, Copenhagen, Denmark, 1994.

[66] H. P. Stirling and I. Okumus, "Growth, mortality and shell morphology of cultivated mussel (Mytilus edulis) stocks crossplanted between two Scottish sea lochs," Marine Biology, vol. 119, pp. 115-123, 1994.

[67] C. Bacher, J. Grant, A. J. S. Hawkins, J. Fang, M. Zhu, and M. Besnard, "Modelling the effect of food depletion on scallop growth in Sungo Bay (China)," Aquatic Living Resources, vol. 16, no. 1, pp. 10-24, 2003.

[68] B. Wang and Z. Wang, "Long-term variations in chlorophyll a and primary productivity in Jiaozhou Bay, China," Journal of Marine Biology, vol. 2011, Article ID 594684, 7 pages, 2011.

[69] S. E. Shumway, T. L. Cucci, R. C. Newell, and C. M. Yentsch, "Particle selection, ingestion, and absorption in filter-feeding bivalves," Journal of Experimental Marine Biology and Ecology, vol. 91, no. 1-2, pp. 77-92, 1985.

[70] C. R. Newell, S. E. Shumway, T. K. Cucci, and R. Selvin, "The effects of natural seston particle size and type on feeding rates, feeding selectivity and food resource availability for the mussel Mytilus edulis Linnaeus, 1758 at bottom sites in Maine," Journal of Shellfish Research, vol. 8, pp. 187-196, 1989.

[71] J. K. Petersen and H. U. Riisgård, "Filtration capacity of the ascidian Ciona intestinalis and its grazing impact in a shallow fjord," Marine Ecology Progress Series, vol. 88, no. 1, pp. 9-17, 1992.

[72] J. M. Navarro and J. E. Winter, "Ingestion rate, assimilation efficiency and energy balance in Mytilus chilensis in relation to body size and different algal concentrations," Marine Biology, vol. 67, no. 3, pp. 255-266, 1982.

[73] P. Jumars, Concepts in Biological Oceanography: An Interdisciplinary Primer, Oxford University Press, Oxford, UK, 1993. 



Submit your manuscripts at

http://www.hindawi.com
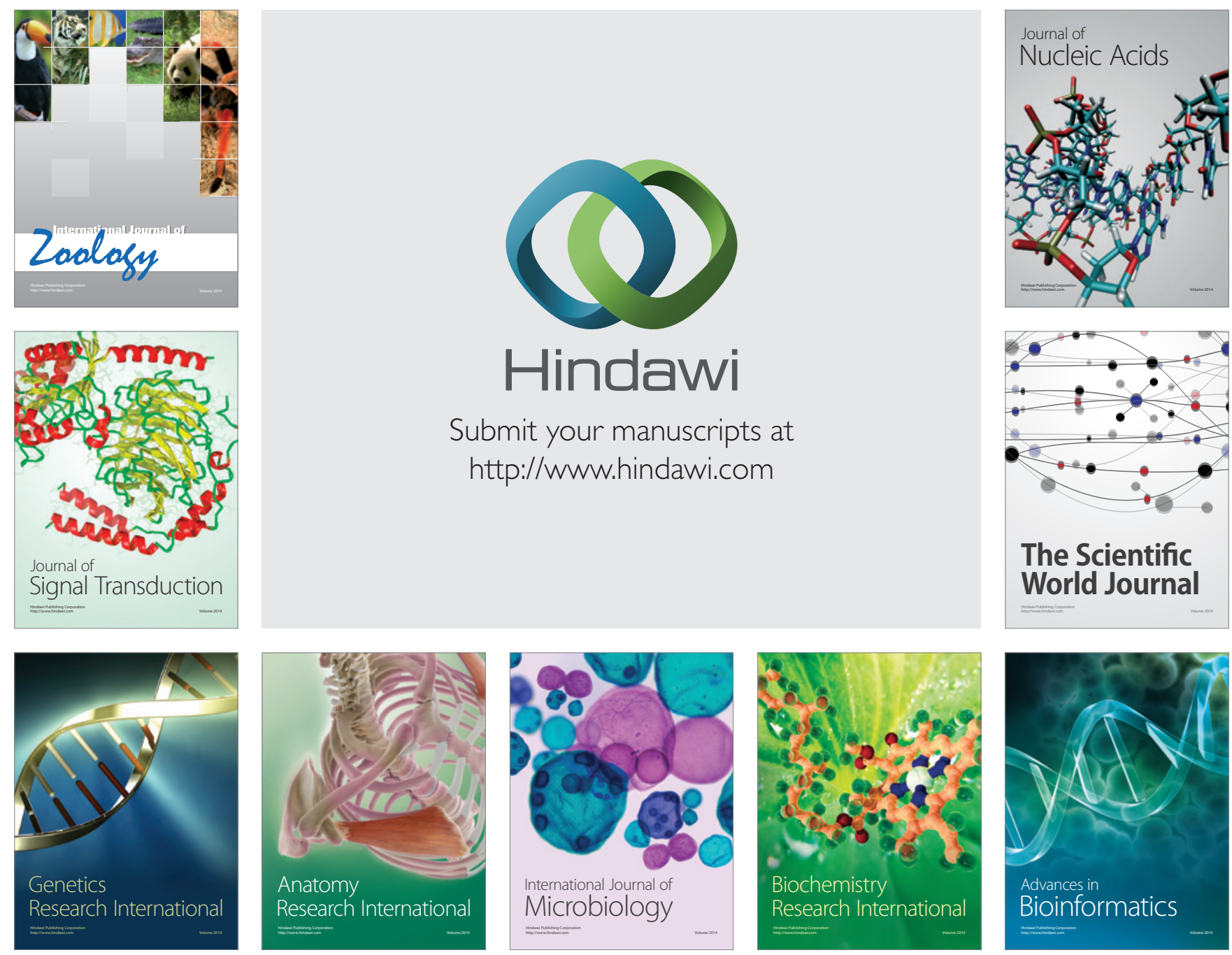

The Scientific World Journal
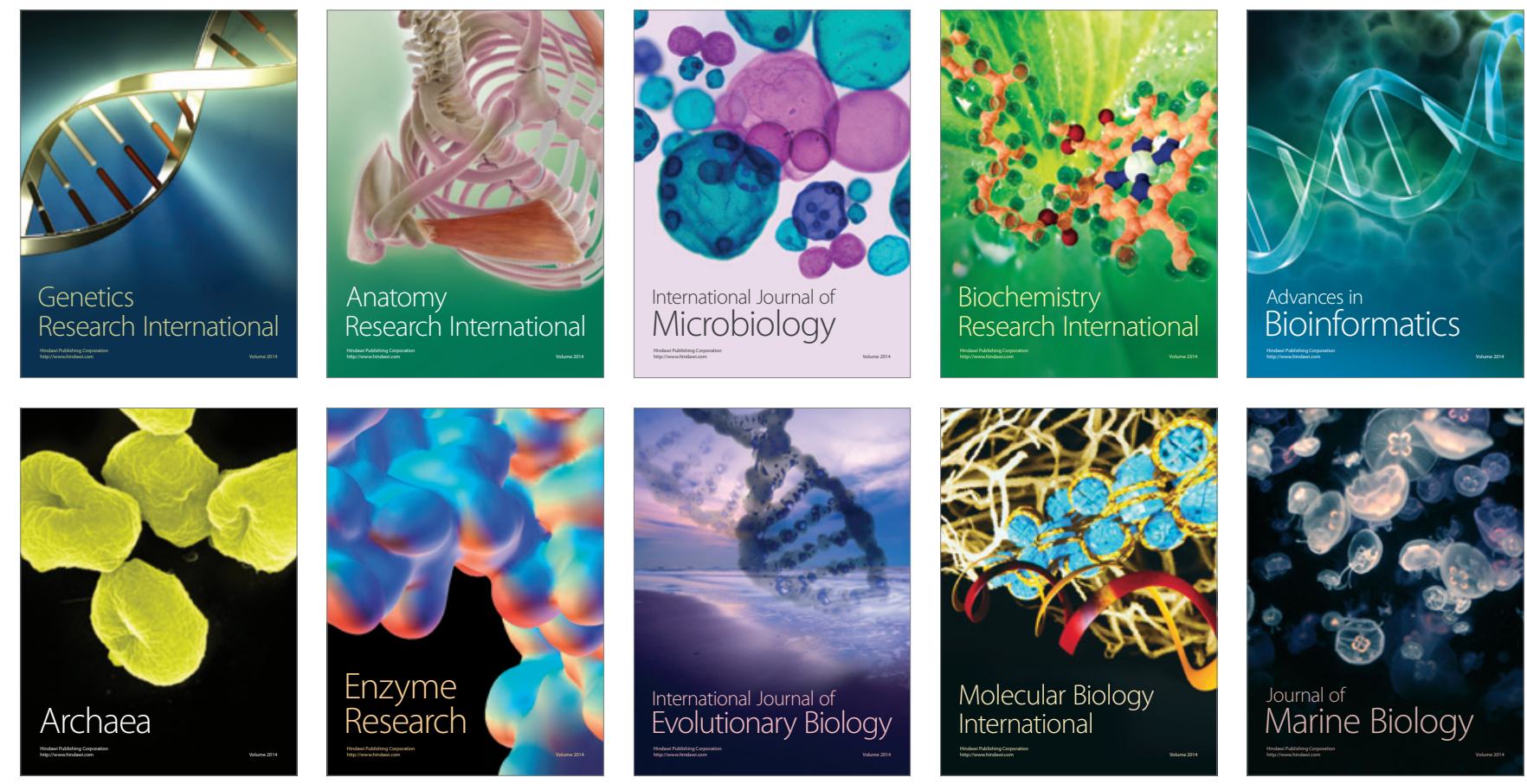